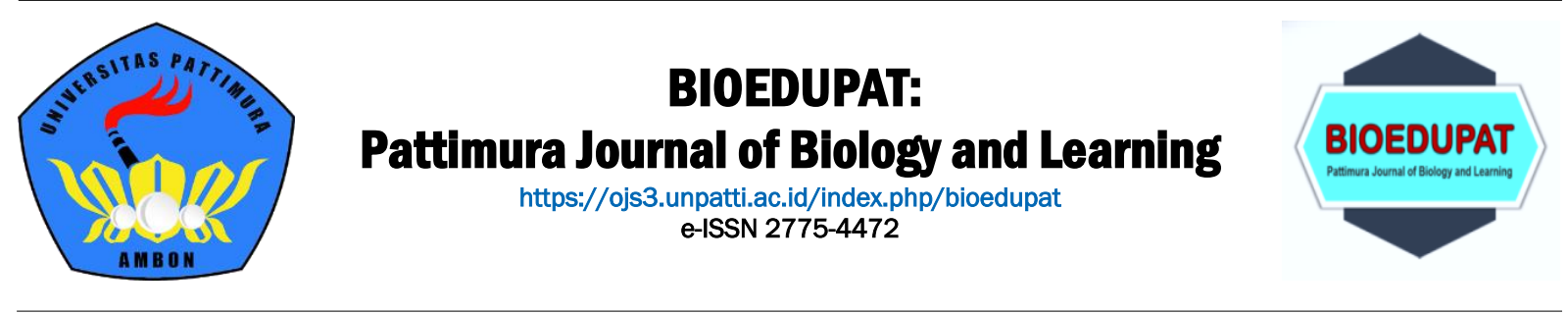

Research Article

\title{
Problem-based learning model: Its application and effect on learning outcomes
}

\author{
La Amaludin $1{ }^{*}$, Johanis F. Rehena ${ }^{2}$, Hermalina Sinay ${ }^{2}$ \\ ${ }^{1}$ Madrasah Ibtidaiyah Swasta, Jl. Trans Seram, Kairatu 97566, Indonesia \\ ${ }^{2}$ Study Program of Biology Education, Faculty of Teacher Training and Education, Pattimura University, \\ Jl. Ir. M. Putuhena, Ambon 97233, Indonesia \\ * corresponding author: la.amaludin05@gmail.com
}

Received: 17 February 2021

Revised: 20 March 2021

Accepted: 21 April 2021

\begin{abstract}
The problem-based learning model is a model that plans a problem that is given by educators to be solved by students. This PBL learning model has learning conditions oriented to concrete problems. This research aimed to determine the effect of the problem-based learning (PBL) model on the learning outcomes of class VIII students on Plant Motion Material at MTs AlMuhajirin Waihatu. The type of research used in this research is descriptive quantitative analyzed using inferential statistics. This research was conducted for three months starting from August 10 to October 10, 2020. The location of this research was carried out in class VIII on Plant Motion Material at MTs Al-Muhajirin Waihatu with a sample of 90 students. To analyze the data obtained through questionnaires and test results, students were processed using descriptive analysis with the SPSS 20 application. The results showed that the application of the problem-based learning (PBL) learning model to the learning outcomes of students in plant motion reached the final qualifications of students (Test Formative) describes 90 students $(100 \%)$ who succeeded in achieving the MCC value (minimum completeness criteria). The problem-based learning model has a significant effect on the learning outcomes of class VIII students of MTs Al-Muhajirin Waihatu, this can be seen from the significant level of 0.626 with the strong category.
\end{abstract}

Keywords: Problem based learning, learning outcome

To cite this article:

Amaludin, L., Rehena, J. F., \& Sinay, H. (2021). Problem-based learning model: Its application and effect on learning outcomes. Bioedupat: Pattimura Journal of Biology and Learning, Vol 1(1), 24-31. DOl: https://doi.org/10.30598/bioedupatv1i1pp24-31

\section{INTRODUCTION}

Education has an important role in human life. The level of human quality can be seen from the quality of education. Education is an activity that is carried out on purpose and in a planned manner carried out by adults who have the knowledge and skills to provide competence to students so that they have basic knowledge, skills, and values that reflect thinking and acting for the creation of the desired human resources, as al-insan-al-Kamil (Idi, 2017). Biology lessons are interesting and fun lessons that are related to everyday life so that biology learning can be carried out properly and achieving maximum learning objectives, students must be able to understand the concepts or material provided by the teacher during the learning process (Kurniawan, 2013). In fact, in learning, of course, some steps need to be considered. These steps are in line with the learning model that is implemented so that the learning model is easily accepted by students. In line with this, educators need to 
change their mindset to help students become more active by applying a scientific approach (Saputri \& Febriani, 2017).

The problem-based learning (PBL) learning model is a model that plans a problem that is given by educators to be solved by students. This PBL learning model has learning conditions oriented to concrete problems. In line with that, learning a basic concept of a subject matter requires a learning model that orientates students to problems in the real world to train students' thinking skills (Trianto, 2015). Students' thinking skills can be guided by solving problems in small groups using a problem-based learning model. A problem given to students will be solved with the ability they have to build concepts in the material they are learning. Thus, with the problem-based learning model, it can train students' ability to solve problems. Learning outcomes are the result of an interaction between teaching and learning activities and are usually indicated by the test scores given by the teacher (Bakkenes et al., 2010). Skaggs \& Bodenhorn (2006) states that learning outcomes indicate learning achievement, while learning achievement is an indicator of the degree of change in student behavior.

The results of the researchers' initial observations at MTs Muhajirin Waihatu are the researchers saw that the learning outcomes were still low. The low learning outcomes of students are due to educators who dominate the learning process. In addition to these factors, educators still use conventional learning models where learning is still centered on educators so that the achievement of student learning outcomes is low. To solve this problem, it is necessary to apply the problem-based learning (PBL) learning model in a condition oriented to concrete problems so that student learning outcomes increase. Furthermore, it is measured how much influence the problem-based learning (PBL) learning model has on student learning outcomes.

According to Riyanto (2009), the application of the problem-based learning model is 1) The teacher gives problems to students who are in small groups. 2) Then, each group discusses the problem their basic knowledge and skills. 3) Students also formulate problems and hypotheses. 4) Students actively seek information and data related to problems that have been formulated, students are diligent in discussing with their groups to solve the problems given by reporting the data that has been obtained. 5) The closing discussion activity is carried out when the process has obtained the right solution. The ability to solve problems can be identified into five indicators, namely: 1) Providing simple explanations, 2) Building basic skills, 3) Concluding, 4) Providing further explanations, 5) Organizing strategies and techniques (Suprijono, 2016). Effect of Problem based learning models. Regarding the learning outcomes above, it is supported by the opinion of Hasibuan (2018) that the factors that influence learning outcomes are classified into two, namely internal factors, which can be in the form of interests, talents, intelligence, perceptions and so on relating to students as individuals.

\section{METHODS}

\section{Types of research}

This research is designed using descriptive quantitative research that is analyzed using inferential statistics. Quantitative research is to see the effect of the problem-based learning (PBL) model on the learning outcomes of class VIII students on Plant Motion Material at MTs Al-Muhajirin Waihatu. This research was conducted from 10 August-10 October 2020. The population in this study included all students of class VIII at MTs Al-Muhajirin Waihatu, totaling 90 people consisting of 3 classes. The sample in this study was a population sample, namely all students of class VIII at MTs Al-Muhajirin Waihatu, totaling 90 students. The independent variable (free) is the PBL learning model $(X)$ and the dependent variable is learning outcomes $(Y)$.

\section{Validity and reliability test}

\section{Validity test}

All factor analysis processes use a computer program Statistics Package Social Science (SPSS) 20.0 for windows. The calculation of the validity test uses SPSS 20 with the criteria for deciding whether an instrument is valid or not, namely by comparing $r$ count with $r$ table, with a confidence level of $95 \%$ and a significance level of $5 \%$. If $r$ count $>r$ is critical, then the statement item is valid, whereas if $r$ count $<r$ is critical, then the statement item is invalid.

\section{Reliability test}

Similar to the validity test, to measure the reliability test, the formula for testing the reliability of the instrument is Alpha Cronbach, and by using the Statistical Package Social Science (SPSS) 20 program for windows. 


\section{Classic Assumption Test}

\section{Normality test}

The way to detect whether the residuals are normally distributed or not is by statistical tests. The statistical test is the Kolmogorov-Smirnov test if the sig (2-tailed) value is greater than $5 \%$, then the data is normally distributed. The basis for decision making can be made based on probability (Asymtotic Significance), namely:

1) If the probability $>0.05$ then the distribution of the population is normal.

2) If the probability $<0.05$ then the population is not normally distributed.

\section{Heteroscedasticity}

The basis of this heteroscedasticity test analysis:

1) If there is a certain pattern such as the dots forming a regular pattern (wavy, widened then narrowed), it indicates that heteroscedasticity has occurred.

2) If there is no clear pattern, and the dots spread above and below the 0 on the $Y$ axis, there is no heteroscedasticity.

\section{Hypothesis test}

\section{Simple linear regression}

The general form of the simple linear regression equation is: $Y=a+b+b x$, where:

$$
\begin{aligned}
& Y=\text { Problem based learning model in the predicted dependent variable } \\
& a=\text { constant number } \\
& b=\text { variable regression coefficient } X \text { (PBL model) }
\end{aligned}
$$

\section{T-test}

Decision making is based on the probability value obtained from the results of data processing through the SPSS Parametric Statistics program as follows:

$T_{\text {count }}>T_{\text {table }}$, then $=$ the independent variable affects the dependent variable.

$T_{\text {count }}<T_{\text {table }}$, then $=$ the independent variable does not affect the dependent variable.

\section{Coefficient of Determination $\left(r^{2}\right)$}

The criteria used to express the relationship between the data distribution of the independent variable $(X)$ and the dependent variable $(Y)$ are stated to be linear if the coefficient of linearity $F$ count is greater than or equal to the value of the $\mathrm{F}$ table at the 5 percent $(5 \%)$ significance level. Decision-making on probability figures, if the probability of the analysis results is $\leq 0.05$ then $\mathrm{HO}$ is rejected and $\mathrm{H} 1$ is accepted, indicating that there is an influence of the learning environment and self-concept on the learning outcomes of students' biology. Data processing using a computer program Statistic package social science (SPSS) 20.0 for Microsoft Office Word For Windows.

\section{RESULTS AND DISCUSSION}

\section{Learning outcomes}

The results of the students' initial tests were obtained from the motion material in plants for the 2020/2021 academic year which was carried out by researchers before the activity and learning process using the problembased learning (PBL) learning model in class VIII MTs Al-Muhajirin Waihatu showed that the highest score obtained by students was 69,09 and the lowest score obtained by students was 40.73 . To more clearly the frequency distribution and percentage of learning outcomes of class VIII students of MTs Al-Muhajirin Waihatu can be seen in the following Table 1.

Tabel 1. Qualification of the presentation of the pre-test interval value

\begin{tabular}{cccc}
\hline $\begin{array}{c}\text { Value Interval } I \\
\text { Score Value }\end{array}$ & Frequency & $\begin{array}{c}\text { Relative } \\
\text { Frequency }(\%)\end{array}$ & Qualification \\
\hline $81-100$ & 0 & 0 & Very good \\
$71-80$ & 0 & 0 & Good \\
$61-70$ & 42 & 46.67 & Adequate \\
$<60$ & 48 & 53.33 & Less \\
Jumlah & 90 & 100 & \\
\hline
\end{tabular}


The data above can be concluded that the ability level of students 'initial test results before participating in the learning process using the problem-based learning (PBL) learning model shows that the students' initial test is low where 42 students with a percentage of $46.67 \%$ indicate qualifications (sufficient), 48 participants students with a percentage of $53.33 \%$ showed qualifications (lacking), no students were able to achieve qualifications (good and very good).

The data above also reveals that the initial test results achieved by the majority of students do not meet the minimum completeness criteria (KKM), which is 67 for individuals and $85 \%$ for classical completeness. It is recognized that there are 17 students or $18.89 \%$ who meet the minimum completeness criteria. This is because the students' knowledge of the material has not been taught so that the level of mastery is at sufficient and insufficient qualifications.

The final test results show the learning outcomes (cognitive, affective, and psychomotor) of students obtained from the learning process using the problem-based learning (PBL) learning model in class VIII MTs Al-Muhajirin Waihatu shows that the highest score obtained by students is 85.00 with very good qualifications and the lowest score obtained by students is 69.00 with sufficient qualifications. Learning outcome data which is a combination of the value of the cognitive, affective, and psychomotor aspects can be seen in the following Table 2.

Tabel 2. Classification of the post-test score presentation

\begin{tabular}{cccc}
\hline $\begin{array}{c}\text { Value Interval } / \\
\text { Score Value }\end{array}$ & Frequency & $\begin{array}{c}\text { Relative } \\
\text { Frequency (\%) }\end{array}$ & Qualification \\
\hline $81-100$ & 49 & 54.44 & Very good \\
$71-80$ & 34 & 37.78 & Good \\
$61-70$ & 7 & 7.78 & Adequate \\
$<60$ & 0 & 0 & Less \\
Jumlah & 90 & 100 & \\
\hline
\end{tabular}

From the table above, it can be concluded that as many as 49 students with a percentage of $54.44 \%$ showed qualifications (very good) to master the indicators with a value (81-100), 34 students with a percentage of $37.78 \%$ showed qualifications (good) to master the indicators with a value (71-80), 7 students with a percentage of $7.78 \%$ showed qualifications (sufficient) to master the indicators with a value (61-70) when compared with (MCC) which had been determined by the average score of achievement of students on the formative test. It can be said that the attainment of learners' knowledge is in the complete category of the MCC which is determined both individually and classical. This proves that after the learning process using the problem-based learning (PBL) learning model on the learning outcomes of students in plant motion to achieve the final ability qualifications of students (Formative Test), it describes 90 students (100\%) successfully achieving the MCC value (completeness criteria minimal).

Research Janah et al. (2018) also show that before the application of the learning model, learning outcomes that reveal students' conceptual understanding of the material is very low compared to after learning. After going through the learning process, students' understanding of plant motion material has increased. Rumahlatu \& Sangur (2019) also explain that learning outcomes are related to students' understanding of a concept formed through the learning process (contextual). It can be seen in the research conducted by Anisa et al. (2018) regarding readiness for independent study. Highly independent students will make them ready to respond/answer in lessons or ready to accept lessons well.

\section{Assumption Requirements Test Normality test}

The normality test is intended to determine whether each variable is normally distributed or not. Data normality testing was carried out using the Statistical Package Science (SPSS) 20.0 computer program by observing the significance of Kolmogorov Smirnov. If the Kolmogorov Smirnov significance value is greater than 0.05 , the data is normally distributed and vice versa, if the Kolmogorov Smirnov significance value is less than 0.05 , the data is not normally distributed. For more details about the normality test of each variable studied, it can be seen in the following Table 3.

Table 3. Summary of the results of the variable normality test

\begin{tabular}{lccc}
\hline \multicolumn{1}{c}{ Variable } & Significance & $\boldsymbol{\alpha}$ & Information \\
\hline Problem based learning model $(X)$ & 0,075 & 0,05 & Normal \\
Learning Outcome $(Y)$ & 0,200 & 0,05 & Normal \\
\hline
\end{tabular}


The table above shows that all variables show a Kolmogorov-Smirnov significance value greater than 0.05 . The problem-based learning model variable has a Kolmogorov Smirnov significance value of 0.075 while learning outcomes have a significance value of 0.200 . It can be concluded that the data from the problem-based learning model variables and learning outcomes are normally distributed.

\section{Linearity test}

The linearity test is intended to test whether the variables affect linearly or not, whether it violates the linearity assumption or not. The variables $X$ and $Y$ affect linearly if they form a linear line. The results of the linearity test between variables using SPSS 20.0 can be seen in the following table:

Table 4. Summary of linearity test results

\begin{tabular}{lccc}
\hline \multicolumn{1}{c}{ Variable } & Sig & $\alpha$ & Info \\
\hline $\begin{array}{l}\text { Problem based learning model }(\mathrm{X}) \\
\text { and learning outcome }(\mathrm{Y})\end{array}$ & 0,00 & 0,05 & Linear \\
\hline
\end{tabular}

The variables $X$ and $Y$ have a linear effect if the significance value of linearity is less than 0.05 . Based on the table above, both problem-based learning model variables have a linear effect on learning outcomes. This is indicated by the significance value of the effect of the problem-based learning model with learning outcomes is 0.00 and the significance value is less than 0.05 . Thus, there is a linear relationship between problem-based learning models and student learning outcomes.

\section{Pituitary Test}

The results of hypothesis testing are used to determine the effect of the independent variables on the dependent variable. The dependent variable data shows a normal and homogeneous distribution so that it is feasible to be tested using statistical tests. The results of the ANOVA calculation on learning outcomes are shown in Table 5, while the coefficient values are shown in Table 6 and Table 7. Residuals Statistics.

Table 5. Anova

\begin{tabular}{llccccc}
\hline & Model & Sum of Squares & df & Mean Square & F & Sig. \\
\hline 1 & Regression & 4325.362 & 1 & 4325.362 & 18.873 & .000 \\
Residual & 343.260 & 88 & 3.901 & & \\
Total & 4668.622 & 89 & & & \\
\hline
\end{tabular}

Table 6. Coefficients

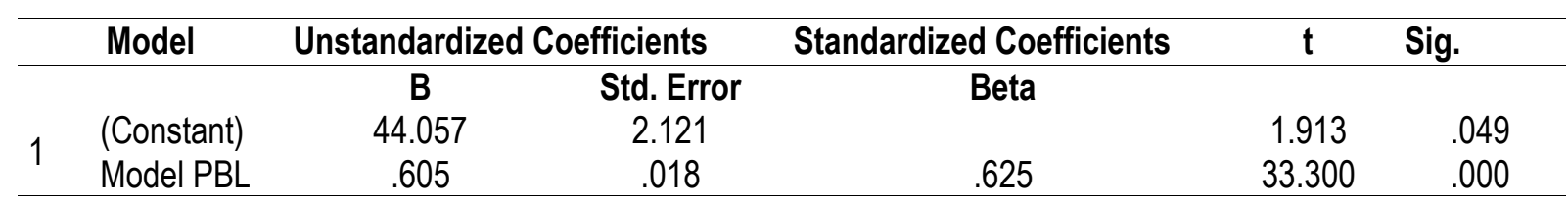

Table 7. Residuals Statistics

\begin{tabular}{lccccc}
\hline & Minimum & Maximum & Mean & Std. Deviation & N \\
\hline Predicted Value & 57.30 & 86.95 & 74.36 & 6.971 & 90 \\
Residual & -2.401 & 13.339 & .000 & 1.964 & 90 \\
Std. Predicted Value & -2.446 & 1.806 & .000 & 1.000 & 90 \\
Std. Residual & -1.216 & 6.754 & .000 & .994 & 90 \\
\hline
\end{tabular}

The results of the measurement of the problem-based learning model associated with the learning outcomes of students processed using SPSS 20.0 for windows obtained the results of simple regression analysis with a coefficient "b" of 44.057 and a constant "a" of 0.605 so that the regression line equation $\hat{Y}=44.057+0.605 X$. The test on the table shows that the value of $F$ count $=18.873$ is greater than the $F$ table at a 0.05 , namely 3.04 with a significant 0.00 much smaller than a 0.05 . This result means that the regression with the equation $\hat{Y}=$ $44.057+0.605 X$ is significant $(p<0.05)$. The regression equation above illustrates that each increase of one score in the problem-based learning $(X)$ learning model causes an increase of 0.605 scores of student learning outcomes at a constant of 44.057. A simple analysis of the score of the problem-based learning model $(X)$ and the score of student learning outcomes $(Y)$ shows the rxy coefficient of 0.626 . 
The test results show that $t=1.913$ is greater than $t$ table 1.66 at $\alpha=0.05$ and $\alpha=0.01$. This means that the power of the effect of the problem-based learning model $(X)$ on student learning outcomes $(Y)$ is significant. The results of the simple linear regression analysis show that the problem-based learning model has a positive effect on the learning outcomes of students at MTs Al-Muhajirin Waihatu. Based on this test, it was obtained a value of 0.626 so that it was concluded that the influence of the problem-based learning model with learning outcomes was high, while the simultaneous contribution or contribution of the problem-based learning model variable and learning outcomes was $39.18 \%$ while $60.82 \%$ was influenced by other factors.

The results of simple linear regression analysis show that there is an influence between the problem-based learning model with the learning outcomes of students on plant motion material in class VIII MTs Al-Muhajirin Waihatu. Thus, it is concluded that if the learning process is carried out using the problem-based learning model for students, there will be an influence on the learning outcomes of class VIII students on the material of plant motion in MTs Al-Muhajirin Waihatu. So, that it is known that the hypothesis $\mathrm{H} 0$ is rejected and hypothesis $\mathrm{H} 1$ is accepted. Although in the descriptive data, it was found that students obtained a score of problem-based learning model which was quite high, but when it was related to learning outcomes it contributed to the influence category with a strong category (0.626).

Learning in the 2013 curriculum requires a change in the mindset of educators to further activate students by applying a scientific approach which aims to improve critical thinking skills. Through these scientific steps, it is hoped that the critical thinking skills of students will develop. Learning curriculum 2013 requires scientific learning, one of which is the PBL model (Azmi et al., 2017). The problem-based learning (PBL) model is a model that plans a problem that is given by educators to be solved by students. This PBL model has a learning condition that is oriented to concrete problems. In line with that, learning a concept and the basis of a subject matter requires a learning model that orientates students to problems in the real world to train students' critical thinking skills (Trianto, 2015). So PBL is a model for solving a problem and stimulating critical thinking of students on learning materials to achieve learning objectives.

The problem-based learning model can affect the learning outcomes of students in biology subjects at MTs Al-Muhajirin Waihatu, this is as seen from the frequency distribution table, it is known that the problem-based learning model is the $X$ variable obtained through giving questionnaires to class students. VIII MTs. Al-Muhajirin Waihatu as a respondent located in Kairatu District, West Seram Regency which includes 3 (three) classes with 90 students having a questionnaire score range 88-137. The highest score for the questionnaire obtained by students was 137 while the lowest score was obtained value 88. Based on the table above shows that most of the students' answers to the questionnaire analysis results of the problem-based learning model were in the high enough categories, namely there were 29 people with a percentage of $32.22 \%$ with a score range of $110-119$.

The effect of the problem-based learning model on student learning outcomes is a positive linear role, meaning that the problem-based learning model is quite high followed by an increase in the learning outcomes of these students. The results of the regression analysis of the problem-based learning model with learning outcomes showed that there was a significant influence with the moderate category, namely 0.626 so that the environment in the study contributed $62 \%$ while $48 \%$ was influenced by other factors. Other factors that are intended do not come from the variables studied.

The results of the inferential analysis that has been carried out to test the first hypothesis regarding the effect of the problem-based learning model with learning outcomes indicate that there is a positive influence between the problem-based learning model and learning outcomes at $\alpha=0.05 \%$. This shows that if the problem-based learning model is good, the learning outcomes will be good. The regression results show that the value between Problem based learning model and student learning outcomes is 0.626 . Referring to the interpretation of the $r$ value proposed by Arikunto (2010), this percentage is in the medium category. The problem-based learning model contributed $62 \%$ to learning outcomes.

The problem-based learning model is a condition that affects the learning process. Because a supportive problem-based learning model it will allow students to learn well, but the problem-based learning model itself will run even better if it is supported by students' conditions because critical thinking skills will provide abilities that can be recognized by students based on characteristics. Physical and psychological disregard that is general or specific, but both problem-based learning models are needed in supporting students in learning activities so that it will help the success of students in learning activities. Because learning outcomes are a process of changing behavior that has been done and done which can be measured based on numbers and values.

The results above illustrate that the problem-based learning model is an indicator in the learning process that affects the achievement of student learning outcomes. It can be said that internal and external factors are two factors in the life of students who can deliberately achieve learning outcomes. From the discussion of the effect of the problem-based learning model on learning outcomes, it shows that the strength of the problem-based learning model with learning outcomes is very high, while the simultaneous contribution of problem-based 
learning model variables and critical thinking skills with learning outcomes is $39 \%$ while $61 \%$ is influenced by other factors.

The internal and external factors that were studied did not contribute $100 \%$ to learning outcomes, so other internal and external factors were not studied that also affected the achievement of learning outcomes. It is seen in research conducted by Raharjo (2010) regarding independent learning readiness. Highly independent students are more ready to respond/answer in lessons or to accept lessons well. Other external factors that support learning outcomes are studied by (Daud, 2012). The results showed that in general learning motivation and learning outcomes were classified as good. This means that if students are motivated to learn, their learning outcomes will be good (high). Conversely, if students have bad habits in learning, their learning outcomes will be bad (low).

From the research that supports that in addition to internal and external factors, the problem-based learning model examined in this study also proves that there are other internal and external factors that support so that learning outcomes can be achieved by students in class VIII MTs Al-Muhajirin Waihatu. Recapitulation of the relationship between the effect of the Problem-based learning model on student learning outcomes. Overall, the variable between the problem-based learning model $(X)$ on learning outcomes $(Y)$ with a regression coefficient value of 0.626 is a strong category.

The influence of the Problem-based learning model on learning outcomes above is supported by the opinion of Taiyeb \& Mukhlisa (2015) that the factors that influence learning outcomes are classified into two, namely internal factors of students, which can be in the form of interests, talents, intelligence, perceptions and so on. relating to students as individuals. And external factors in the form of the influence of the surrounding environment, namely including the natural environment and socio-cultural environment, as well as the non-social or instrumental environment, which includes curriculum, programs, learning facilities, teachers.

\section{CONCLUSION}

The application of the problem-based learning (PBL) learning model to the learning outcomes of students in plant movements to achieve the final ability qualifications of students (Formative Tests) describes 90 students $(100 \%)$ successfully achieving the KKM value (minimum completeness criteria). The problem-based learning model has a significant effect on the learning outcomes of class VIII students of MTs AI-Muhajirin Waihatu, this can be seen from the significant level of 0.626 with the strong category.

\section{REFERENCES}

Arikunto, S. (2010). Metode peneltian. Rineka Cipta, Jakarta.

Azmi, M. K., Rahayu, S., \& Hikmawati, H. (2017). Pengaruh model problem based learning dengan metode eksperimen dan diskusi terhadap hasil belajar fisika ditinjau dari sikap ilmiah siswa kelas X MIPA SMA N 1 Mataram. Jurnal Pendidikan Fisika dan Teknologi, 2(2), 86-94.

Bakkenes, I., Vermunt, J. D., \& Wubbels, T. (2010). Teacher learning in the context of educational innovation: Learning activities and learning outcomes of experienced teachers. Learning and instruction, 20(6), 533-548.

Daud, F. (2012). Pengaruh kecerdasan emosional (EQ) dan motivasi belajar terhadap hasil belajar Biologi siswa SMA 3 Negeri Kota Palopo. Jurnal Pendidikan dan Pembelajaran, 19(2), 243-255.

Idi, A. (2017). Sosiologi Pendidikan [Sociology of Education]. Rajagrafindo Persada, Jakarta.

Hasibuan, E. K. (2018). Analisis kesulitan belajar matematika siswa pada pokok bahasan bangun ruang sisi datar di smp negeri 12 bandung. Axiom: Jurnal Pendidikan dan Matematika, 7(1), 1-11.

Kurniawan, A. D. (2013). Metode Inkuiri Terbimbing Dalam Pembuatan Media Pembelajaran Biologi Untuk Meningkatkan Pemahaman Konsep Dan Kreatifitas Siswa SMP. Jurnal Pendidikan IPA Indonesia, 2(1), 8-11.

Raharjo, S. B. (2010). Pendidikan karakter sebagai upaya menciptakan akhlak mulia. Jurnal Pendidikan dan Kebudayaan, 16(3), 229-238.

Riyanto, Y. (2009). Paradigma Baru Pembelajaran Sebagai Referensi bagi Pendidikan dalam Implementasi Pembelajaran yang Efektif [New Paradigm of Learning as a Reference for Education in the Implementation of Effective Learning]. Kencana, Jakarta.

Rumahlatu, D., \& Sangur, K. (2019). The influence of project-based learning strategies on the metacognitive skills, concept understanding, and retention of senior high school students. Journal of Education and Learning, 13 (1), 104-110.

Saputri, D. A., Febriani, S. (2017). Pengaruh model problem based learning (PBL) terhadap kemampuan pemecahan masalah peserta didik pada mata pelajaran biologi materi pencemaran lingkungan kelas $X$ MIA SMA N 6 Bandar Lampung [The influence of problem based learning (PBL) model on students' problem-solving ability in biology subjects environmental pollution material class X MIA SMA N 6 Bandar Lampung]. Journal of Biological Education Tadris, 8(1), 40-52. 
Suprijono, A. (2016). Model Pembelajaran Emansipatoris [Emancipatory Learning Model]. Pustaka Pelajar, Surabaya.

Skaggs, G., \& Bodenhorn, N. (2006). Relationships between implementing character education, student behavior, and student achievement. Journal of Advanced Academics, 18(1), 82-114.

Taiyeb, A. M., \& Mukhlisa, N. (2015). Hubungan Gaya Belajar dan Motivasi Belajar dengan Hasil Belajar Biologi Siswa Kelas XI IPA SMA Negeri 1 Tanete Rilau [The Relationship between Learning Style and Learning Motivation with Biology Learning Outcomes of Class XI IPA Students of SMA Negeri 1 Tanete Rilau]. Bionature, 16(1), 8-16. doi: https://doi.org/10.35580/bionature.v16i1.1563

Trianto. (2015). Model Pembelajaran Terpadu [Integrated Learning Mode]]. Bumi Aksara, Jakarta. 